\title{
Detection of hepatitis $B$ virus DNA among accepted blood donors in Nanjing, China
}

Yong Liu' ${ }^{1,4+}$, Ping $\mathrm{Li}^{2+}$, Cuiping $\mathrm{Li}^{2}$, Jinyong Zhou ${ }^{1,4}$, Chao Wu${ }^{3}$, Yi-Hua Zhou ${ }^{1,3,4^{*}}$

\begin{abstract}
Background: Posttransfusion hepatitis B virus (HBV) infection still occurs although its incidence has been substantially reduced since the introduction of screening of hepatitis B surface antigen (HBsAg) in blood donors. This study aimed to investigate the occult HBV infection in accepted blood donors in Nanjing, China.

Results: The lower detection limit of the nested PCR in this study was estimated to be 20 copies/ml HBV DNA. The positive rate of occult HBV infection was $0.13 \%$ (5 of 2972) in the accepted blood donors. Sequencing data showed that the amplified HBV sequences were not identical each other and to the known sequences cloned in our laboratory, excluding the false-positive caused by cross-contamination. Phylogenetic analysis showed that the HBV in all five donors was genotype B; a single base deletion was detected in the S region of HBV DNA from one donor, and no mutation was observed in the "a" determinant of HBsAg from four other donors. All five donors were negative for anti-HBs and one was positive for anti-HBC.

Conclusions: The prevalence of occult HBV infection in the accepted blood donors in Nanjing, China is relatively high. The data would be meaningful in adapting strategy to eliminate posttransfusion HBV infection in China.
\end{abstract}

\section{Background}

Hepatitis B virus (HBV) infection is one of the major health problems worldwide. The infection is usually defined by the presence of hepatitis B surface antigen (HBsAg) in serum or plasma. However, HBV may exist in humans without detectable HBsAg but with presence of HBV DNA in the serum and/or in the liver, i.e. the occult HBV infection [1]. The occult infection may result from the low viral load in circulation (usually $<200 \mathrm{IU} / \mathrm{ml}$ ) [2] or a mutant HBsAg which is not recognized by the monoclonal antibodies against HBsAg (anti-HBs) used in some commercial detection kits [1,3].

Because of routine screening of blood donors for HBsAg, the incidence of transfusion-transmitted hepatitis $B$ has been steadily reduced over the last four decades; however HBV transmission remains the most frequent transfusion-transmitted viral infection [4-6]. The residual risk of HBV transmission by transfusion is mainly associated with occult HBV infection in blood

\footnotetext{
* Correspondence: yzh20061111@yahoo.com

+ Contributed equally

'Department of Laboratory Medicine, Nanjing Drum Tower Hospital, Nanjing University Medical School, Nanjing, China

Full list of author information is available at the end of the article
}

donors. Additionally, occult HBV infection also has significance in bone marrow and organ transplantations [2,7-9].

Attributed to widespread use of hepatitis $B$ vaccine and other strategies for control of HBV infection, the prevalence of HBsAg carrier rate in general population in China decreased from some $10.0 \%$ in $1980 \mathrm{~s}$ to $7.2 \%$ in 2006 [10-12]. However, HBV infection is still endemic in China. Studies have shown that the prevalence of occult HBV infection is closely related to the endemicity of HBV infection $[13,14]$, however, the occult HBV infection in China has been less studied [15-17]. Thus, we performed this study to investigate the prevalence of occult HBV infection in blood donors in Nanjing, an eastern region of China.

\section{Results}

\section{The sensitivity of the nested PCR}

To determine the sensitivity of the nested PCR developed in this study, we performed the PCR using 10-fold serially diluted template DNA extracted from a plasma with a concentration of 2000 copies/ml HBV DNA. As shown in Figure 1, the minimum copies detected by the three sets of the primers were all 20 copies/ml HBV 


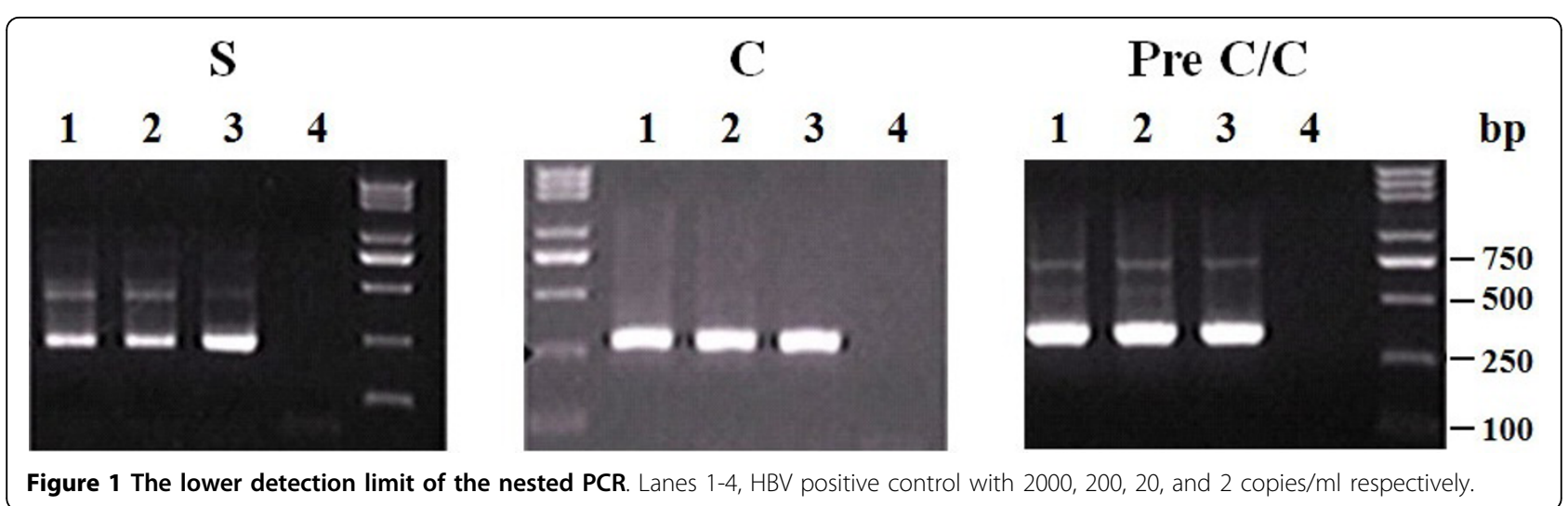

DNA, equivalent to 1 copy per reaction. Thus, the lower detection limit of the nested PCR using the different primers was comparable.

\section{Positive rate of HBV DNA in accepted blood donors}

The samples in which HBV DNA was detected by at least two sets of the primers were considered to be positive for HBV. Of the 2972 accepted blood donors, $5(0.17 \%)$ were determined to have occult HBV infection (Table 1). The plasmas of the nested PCR positive samples were also measured by fluorescent real-time PCR, and the results showed that the viral load in each sample was less than 500 copies $/ \mathrm{ml}$. However, when the three plasmas $(200 \mu \mathrm{l}$ for each) were subjected to DNA extraction and the extracted DNA was dissolved in $20 \mu \mathrm{l}$ TE buffer, HBV DNA became detectable by the fluorescent quantitation PCR with $2.1 \times 10^{3}$ and $1.2 \times 10^{4}$ copies $/ \mathrm{ml}$ respectively. Compared with the final volume of $40 \mu \mathrm{l}$ DNA extracted from $20 \mu \mathrm{l}$ plasmas according to the instruction of the real-time PCR kit, the DNA extraction steps in this study actually concentrated the plasma DNA with 20-fold. Thus, by reverting the concentrated DNA to the original level, the actual viral loads in these two plasmas were

Table 1 Laboratory data of donors with occult HBV infection $^{a}$

\begin{tabular}{|c|c|c|c|c|c|}
\hline \multirow[t]{2}{*}{ Sample ID } & \multicolumn{3}{|c|}{ Primers } & \multirow[t]{2}{*}{ Viral load $^{\text {b }}$ (copies/ml) } & \multirow[t]{2}{*}{ Anti-HBc } \\
\hline & $\mathbf{S}$ & Pre $\mathrm{C} / \mathrm{C}$ & $C$ & & \\
\hline 471 & $P$ & ND & $P$ & ND & $\mathrm{N}$ \\
\hline 686 & $P$ & ND & $P$ & ND & $\mathrm{N}$ \\
\hline 878 & $P$ & ND & $P$ & 110 & $P$ \\
\hline 1473 & $P$ & $P$ & $\mathrm{~N}$ & 105 & $\mathrm{~N}$ \\
\hline 1475 & $P$ & $P$ & $P$ & 600 & $\mathrm{~N}$ \\
\hline \multicolumn{6}{|l|}{ ND: not done } \\
\hline \multicolumn{6}{|l|}{$\mathrm{N}$ : negative } \\
\hline \multicolumn{6}{|l|}{ P: positive } \\
\hline
\end{tabular}

approximately 105,110 , and 600 copies/ml respectively (Table 1).

Of the five HBV DNA positive samples, one was positive for anti-HBc and four others were negative, and all of them were negative for anti-HBs. The ALT of all the positive samples was normal (Table 1).

\section{HBV sequencing and genotyping}

The PCR products amplified by the $S$ region primers were sequenced; the readable sequences were more than $180 \mathrm{bps}$ and contained the sequences of the "a" determinant of HBsAg. Sequencing data demonstrated that none of them was identical to the known sequences detected in our laboratory and there were at least 2 bps differences among the different plasmas, excluding the false positive caused by cross-contamination. A single base deletion was detected in the $\mathrm{S}$ region from a donor, and no mutation in the "a" determinant was observed in four other donors after comparing with the known wild sequences in the GenBank. Phylogenetic analysis of the partial S-gene sequences from the five samples and corresponding sequences recovered from GenBank demonstrated that the viruses in the five samples all belonged to genotype B (Figure 2).

\section{Discussion}

We investigated the occult $\mathrm{HBV}$ infection by detecting HBV DNA in plasmas from accepted blood donors in China with nested PCR and found that the positive rate of HBV DNA was $0.17 \%(5 / 2972)$. Compared with the risk of posttransfusion $\mathrm{HBV}$ infection in countries in which nucleic acid amplification tests (NAT) are used to screen HBV in blood donors [18,19], the data in the present study indicate that there is still substantial risk for posttransfusion $\mathrm{HBV}$ infection in China despite screening for HBsAg in blood donors.

Although nested PCR is sometimes associated with the risk of false-positive results, the HBV DNA detected in this study is unlikely to be caused by cross-contamination 


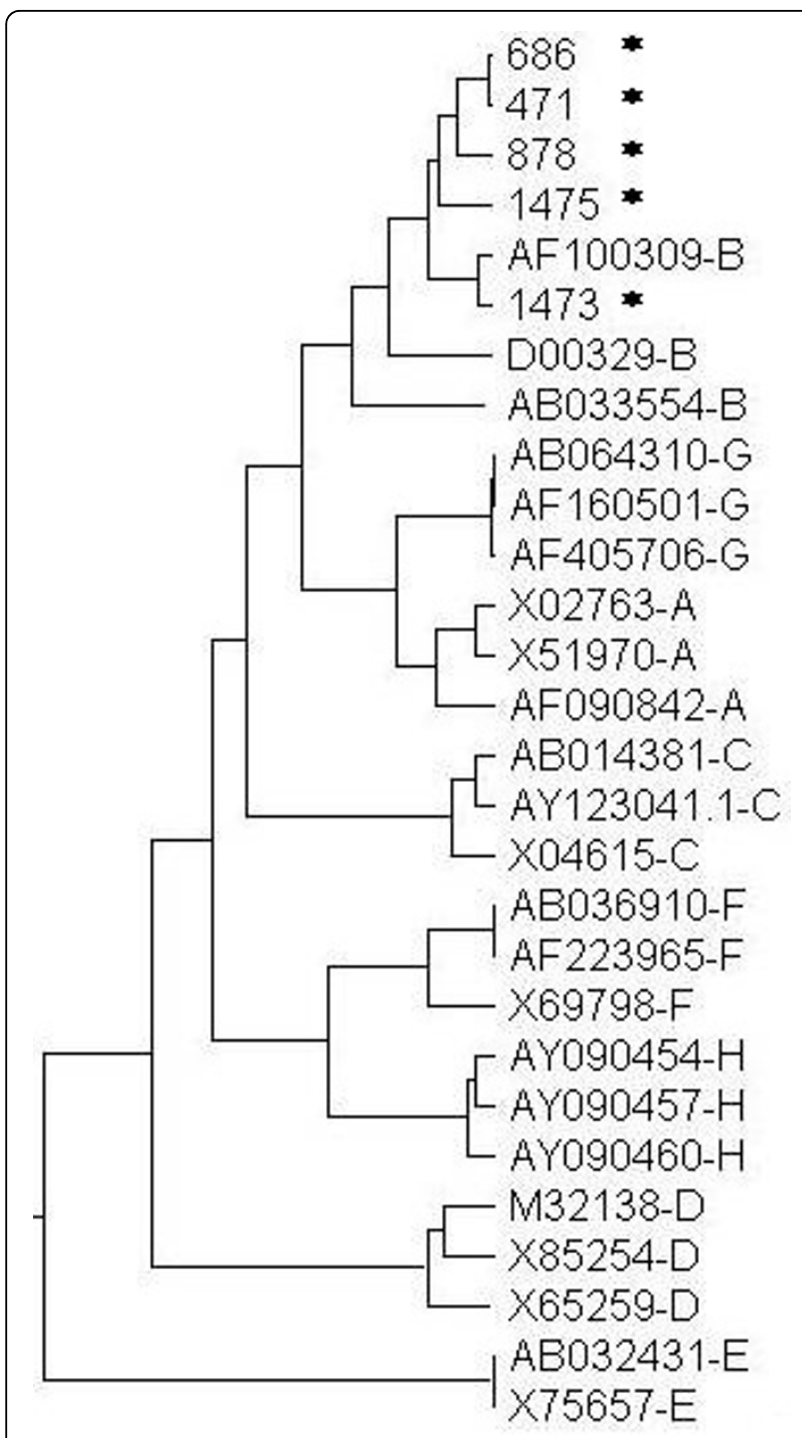

Figure 2 Phylogenetic analysis of $\mathrm{S}$ region of HBV. Phylogenetic tree of the partial $S$ gene sequences (185 bp) from five donors with occult HBV infection in this study and sequences recovered from GenBank. Sequences retrieved from GenBank are denoted by their accession numbers and genotype. ${ }^{*}, \mathrm{~S}$ gene sequences obtained in this study.

or carryover because of the following reasons: (1) we took particular precautions in performing each PCR step as suggested by Kwok and Higuchi [20]; (2) the DNA extraction and each PCR round were undertaken in different rooms; (3) the positive samples were separately tested with two different sets of primers and retested by real-time PCR; and (4) most importantly, the sequencing data showed that all sequences of the positive samples were not identical to each other and to the sequences amplified in our laboratory. On the other hand, the nested PCR used in this study was highly sensitive as it detected as low as 20 copies/ml HBV DNA (Figure 1).
Although detection of HBV DNA using liver tissue DNA extracts can increase the positive rate of occult $\mathrm{HBV}$ infection [21], it is not feasible to get liver tissues from the blood donors. Thus, under the current circumstance and with the available techniques, the positive rate of occult HBV infection detected in this study is less likely to be underestimated.

The prevalence of occult HBV infection in blood donors appears to be varied in different countries or even in different areas in a country. The variations may be associated with the different assays used in the various surveys and the HBV endemicity. It has been documented that low, intermediate, or high endemic areas have different occult HBV infection rate; the NAT tests in blood donors demonstrated that occult HBV infection in regions with low HBV endemicity, such as Western countries is rare, whereas in Japan and Hong Kong it is much higher [22]. Indeed, the occult HBV infection rate $(0.17 \%)$ in blood donors in the present study is higher than that in Western countries like Canada and Germany [23,24], and comparable to that in Ghana [25].

In China, a few relevant studies show substantially divergent prevalence of occult HBV infection in the blood donors, ranging from $0.028 \%(8 / 28800)$ in Guangdong Province [26] and 2.71\% (18/1698) in Zhejiang Province [27] to as high as $9.78 \%(57 / 583)$ in Hunan Province [28]. The relatively low rate in Guangdong may be due to the mini-pool (24 samples) approach used in that study. In the present study, we used realtime PCR to detect HBV DNA in all five plasmas with occult HBV infection, but none of them had a detectable level at a lower detection limit of 500 copies $/ \mathrm{ml}$. On the other hand, the high frequency of $9.8 \%$ found among accepted blood donors in Hunan [28] is questionable, since that report did not exclude the possibility of cross-contaminations.

Several factors are involved in the recognition of the occult HBV infection, including viral variants carrying mutant HBsAg that are not recognized by specific antibodies used in assays for HBsAg [29-32] and low level expression of HBV genes [33-35]. In the present study, the mutation in the "a" determinant of $\mathrm{S}$ region was observed in only one donor and there was no mutation in the "a" determinant in four other donors, yet their HBV DNA levels were only between 105 and 600 copies/ $\mathrm{ml}$. Thus, strong suppression of viral replication and gene expression may have resulted from the host immune responses [36]. Alternatively, since four of the five occult infections did not show any serological HBV markers, it is also possible that these samples were collected during the seroconversion window period, in which case further follow-up may have identified this serologic phenomenon [37]. However, this issue can not be clarified since we did not follow-up these blood donors. 
The occurrence of posttransfusion hepatitis B in China has been substantially reduced since the introduction of HBsAg screening of blood donors. However, the true incidence remains unknown because of the obstacles in conducting such studies. In the present survey, we found that $0.17 \%$ of the accepted blood donors had occult HBV infection, which is much higher than that observed in Western counties as well as in Japan and Hong Kong. Although the conversion of residual risk of occult $\mathrm{HBV}$ infection into the true rate of infection is largely unknown, the results in the chimpanzee model demonstrate that as low as 10 copies of HBV may result in half of the animals being infected, irrespective of HBV genotype [38,39]. Considering that our blood donors had HBV DNA exceed 100 copies/ml, the recipients of these five occult HBV carrier donors were highly possible to be infected with HBV although we did not follow-up the recipients. Indeed, numerous reports have documented that occult HBV infection in blood donors may cause posttransfusion hepatitis B [40-42].

Currently, only a few financially prosperous cities in China detect HBV DNA in blood donors by minipool NAT. We consider that NAT for HBV DNA as a routine screening in blood donors in China will be costeffectiveness, since the risk of HBV transmission by transfusion in China is relatively high based on our data. Even in countries with low HBsAg prevalence such as USA and some European countries, minipool NAT has been used as a routine test in blood donors [43].

\section{Conclusions}

The data in the present study will be meaningful in setting up a strategy to prevent posttransfusion hepatitis B in China. Because of relatively high rate of occult HBV infection in blood donors in China, tests for HBV DNA in blood donors would substantially reduce the incidence of posttransfusion hepatitis B.

\section{Methods}

\section{Blood donors}

We randomly collected plasma samples from 2972 accepted volunteer donors at the Nanjing Red Cross Blood Center between February 2007 and April 2008. Each sample was not directly collected from the donor, but collected from one tubing segment connected to the bag of the donor's blood; each tubing segment was cut with a fresh blade to avoid cross-contamination among samples. According to the policy set up by the China Health Ministry, an accepted donor is defined as a generally healthy person with normal alanine aminotransferase (ALT), negative for HBsAg and antibodies against hepatitis $\mathrm{C}$ virus ( $\mathrm{HCV}$ ), $\mathrm{HIV}$, and treponema pallidum. Thus, the laboratory tests in all the 2972 donors showed to be normal ALT and negative for HBsAg, anti-HCV,
anti-HIV, and antibody against treponema pallidum; the HBsAg in each donor was tested in parallel by two different commercial enzyme-linked immunosorbent assay (ELISA) kits. The donors' average age was 24.9 years (range, 18-53). They were 1475 males and 1497 females. The plasmas were stored at $-20^{\circ} \mathrm{C}$. All the experiments were approved by the Ethics Committee of Nanjing Drum Tower Hospital, Nanjing University Medical School, in accordance with guidelines of the Nation Health and Medical Research Council of China.

\section{Plasma DNA isolation}

DNA was extracted from plasma using phenol-chloroform extraction by the standard method. Briefly, $200 \mu \mathrm{l}$ plasma was treated with proteinase $\mathrm{K}$ at $50^{\circ} \mathrm{C}$ for $3 \mathrm{~h}$, and then DNA was extracted twice by phenol-chloroform and rinsed once by $70 \%$ ethanol. Finally, $20 \mu \mathrm{l}$ Tris-EDTA (TE) buffer was added to each sample to dissolve DNA.

\section{Detection of HBV-DNA by nested PCR}

Nested PCR was performed using specific primers derived from the regions coding for $\mathrm{HBsAg}$, hepatitis B core antigen $(\mathrm{HBcAg})$ and pre- $\mathrm{C}$ respectively as previously reported with minor modifications [44-46]. Primer sequences are shown in Table 2 . In brief, the first round PCR was carried out in a final volume of $50 \mu \mathrm{l}$ containing 1.25 units of Taq polymerase (Takara, Dalian, China) and $5 \mu \mathrm{l}$ DNA template. The amplification was carried out for 35 cycles (20 seconds at $94^{\circ} \mathrm{C}, 30$ seconds at $55^{\circ} \mathrm{C}, 45$ seconds at $72^{\circ} \mathrm{C}$ ) after initial denaturation for $2 \mathrm{~min}$. A final extension step was performed for $10 \mathrm{~min}$ at $72^{\circ} \mathrm{C}$. The second round PCR was carried out using $5 \mu \mathrm{l}$ of the first PCR product under the same condition as the first round PCR except $25 \mathrm{pmol}$ of each internal primer was used. The PCR products were electrophoresed on $1.5 \%$ agarose gel and stained with

Table 2 Primers used for nested PCR

\begin{tabular}{cclc}
\hline Region & Name & Sequences 5' to 3' & $\begin{array}{c}\text { Amplicon } \\
\text { size (bp) }\end{array}$ \\
\hline S & 1stS192F & TCGTGTACAGGCGGGGTT & 513 \\
& 1stS704R & CGAACCACTGAACAAATGGC & \\
& 2ndS455F & CAAGGTATGTGCCCGTTG & 233 \\
& 2ndS687R & GGCACTAGTAAACTGAGCCA & \\
\hline C & 1stC1869F & ACTGTTCAAGCCTCCAAGCT & 600 \\
& 1stC2468R & GGAATACTAACATTGAGATTCCCGAG & \\
& 2ndC2015F & TGCTCTGTATCGGGAGGC & 280 \\
& 2ndC2294R & AGTGCGAATCCACACTC & \\
\hline Pre C/ & 1st 2023F & GCCTTAGAGTCTCCTGAGCA & 442 \\
C & & & \\
& 1st 2464R & GTCCAAGGAATACTAAC & 340 \\
& 2nd 2046F & CCTCACCATACTGCACTCA & \\
\hline & 2nd 2385R & GAGGGAGTCTTCTTCTAGG & \\
\hline
\end{tabular}


ethidium bromide, and then photographed by image analysis system (UVP, Upland, CA).

To determine the lower detection limit of the nested PCR in this study, we carried out the PCR using 10-fold serially diluted template DNA, which was extracted from a sample with known concentration of HBV DNA with 2000 copies $/ \mathrm{ml}$. The DNA was extracted from $200 \mu \mathrm{l}$ serum and dissolved in $200 \mu \mathrm{l}$ TE.

To prevent carryover or cross contamination during the extraction of DNA from plasmas and PCR, each step of the procedure was performed in separate areas with dedicated equipment. Negative controls, including plasmas DNA from normal subjects without HBV infection and distilled water, and a positive control (an HBV DNA positive plasma diluted to 20 copies $/ \mathrm{ml}$ ) were always included in every nested PCR test.

\section{Quantitative assay of HBV DNA}

Plasma HBV DNA in occult HBV infections was quantified by real-time PCR with a commercially available fluorescent real-time PCR assay (Shenyou Biotechnology, Shanghai, China) which had a strict internal quality control and passed the Clinical Laboratory Center of Chinese Ministry of Health external quality assessment on the DNA Engine Opticon 2 System (MJ Research, Waltham, MA). Plasma DNA was extracted using a commercial kit (Shenyou Biotechnology) from $20 \mu \mathrm{l}$ plasma by boiling. The PCR was run for 40 cycles and the fluorescence signal of the amplicons was detected by the DNA Engine Opticon 2 System. The lower detection limit of this assay was $500 \mathrm{copies} / \mathrm{ml}$ with a linear range of up to $10^{8}$ copies $/ \mathrm{ml}$.

\section{Detection of serological markers for HBV infection}

Anti-HBc of the HBV DNA positive samples was measured by ELISA using the Diagnostic kit (Huakang Biotechnology, Shenzhen, China) for anti-HBc.

\section{HBV DNA sequencing and HBV genotyping}

The PCR products amplified by $\mathrm{S}$ region primers were purified and directly sequenced on an ABI Prism 3130 sequencer (Applied Biosystems, Hitachi, Tokyo, Japan) after reaction with BigDye Terminator v3.1 (Applied Biosystems, Foster, CA). Sequence analysis and comparison were conducted by using molecular programs deposited in the web site of the National Centre for Biotechnology Information http://www.ncbi.nlm.nih.gov/. The sequences were compared with the same region of HBV sequences from different genotypes found in the genotyping reference set available on the NCBI website (URL: http://www.ncbi.nih.gov/projects/genotyping/view. cgi? $\mathrm{db}=2)$. The phylogenetic tree was constructed according to previous methods [47].

\section{Acknowledgements}

This study was supported by a Special Research Grant (RC2007005) for the Principal Fellow from the Department of Health, Jiangsu Province, and by a grant (No. 200801088) from the Department of Science and Technology of Nanjing City, China.

\section{Author details}

'Department of Laboratory Medicine, Nanjing Drum Tower Hospital, Nanjing University Medical School, Nanjing, China. ${ }^{2}$ Department of Transfusion Medicine, Nanjing Drum Tower Hospital, Nanjing University Medical School, Nanjing, China. ${ }^{3}$ Department of Infectious Diseases, Nanjing Drum Tower Hospital, Nanjing University Medical School, Nanjing, China. Jiangsu Key Laboratory for Molecular Medicine, Nanjing University Medical School, Nanjing, China.

\section{Authors' contributions}

$Y L$ and $P L$ performed the experiments, analyzed the data, and drafted the manuscript and contributed equally to this work. $\mathrm{CL}$ collected the samples and assisted in the performance of the experiments. JZ carried out the DNA sequencing. CW interpreted the data and revised the manuscript. YHZ designed the study, interpreted the data and critically revised the manuscript. All authors read and approved the final manuscript.

\section{Competing interests}

The authors declare that they have no competing interests.

Received: 2 July 2010 Accepted: 19 August 2010

Published: 19 August 2010

\section{References}

1. Gerlich WH, Bremer C, Saniewski M, Schuttler CG, Wend UC, Willems WR, Glebe D: Occult hepatitis B virus infection: detection and significance. Digest Dis 2010, 28:116-125.

2. Raimondo G, Allain JP, Brunetto MR, Buendia MA, Chen DS, Colombo M, Craxi A, Donato F, Ferrari C, Gaeta GB, Gerlich WH, Levrero M, Locarnini S, Michalak T, Mondelli MU, Pawlotsky JM, Pollicino T, Prati D, Puoti M, Samuel D, Shouval D, Smedile A, Squadrito G, Trepo C, Villa E, Will H, Zanetti AR, Zoulim F: Statements from the Taormina expert meeting on occult hepatitis B virus infection. J Hepatol 2008, 49:652-657.

3. Zhang $R$, Wang $L$, Li J: Hepatitis $B$ virus transfusion risk in China: proficiency testing for the detection of hepatitis B surface antigen. Transfusion Med 2010.

4. Niederhauser C, Mansouri Taleghani B, Graziani M, Stolz M, Tinguely C, Schneider P: Blood donor screening: how to decrease the risk of transfusion-transmitted hepatitis B virus? Swiss Med Wkly 2008, 138:134-141.

5. Calderon GM, Gonzalez-Velazquez F, Gonzalez-Bonilla CR, Novelo-Garza B, Terrazas JJ, Martinez-Rodriguez ML, Cortes-Marquez SR, Blanco-Flores JP, Rodriguez-Rodriguez A, Del Campo MA, Cortes-Gomez R, MejiaBocanegra MG: Prevalence and risk factors of hepatitis $C$ virus, hepatitis $B$ virus, and human immunodeficiency virus in multiply transfused recipients in Mexico. Transfusion 2009, 49:2200-2207.

6. Kafi-abad SA, Rezvan H, Abolghasemi H, Talebian A: Prevalence and trends of human immunodeficiency virus, hepatitis $B$ virus, and hepatitis $C$ virus among blood donors in Iran, 2004 through 2007. Transfusion 2009, 49:2214-2220.

7. Hollinger FB: Hepatitis B virus infection and transfusion medicine: science and the occult. Transfusion 2008, 48:1001-1026.

8. Giudice CL, Martinengo M, Pietrasanta P, Bocciardo L, Malavasi C, Rastelli S, Faraci M, Tripodi G: Occult hepatitis B virus infection: a case of reactivation in a patient receiving immunosuppressive treatment for allogeneic bone marrow transplantation. Blood transfus 2008, 6:46-50.

9. Raimondo G, Pollicino T, Romano L, Zanetti AR: A 2010 update on occult hepatitis B infection. Pathol Biol 2010, 58:254-257.

10. Liang X, Bi S, Yang W, Wang L, Cui G, Cui F, Zhang Y, Liu J, Gong X, Chen Y, Wang F, Zheng H, Wang F, Guo J, Jia Z, Ma J, Wang H, Luo H, Li L, Jin S, Hadler SC, Wang Y: Epidemiological serosurvey of hepatitis B in China-declining HBV prevalence due to hepatitis $B$ vaccination. Vaccine 2009, 27:6550-6557.

11. Zhou YH, Wu C, Zhuang H: Vaccination against hepatitis B: the Chinese experience. Chin Med J (Engl) 2009, 122:98-102. 
12. Zhang S, Li RT, Wang Y, Liu Q, Zhou YH, Hu Y: Seroprevalence of hepatitis $B$ surface antigen among pregnant women in Jiangsu, China, 17 years after introduction of hepatitis B vaccine. Int J Gynecol Obstet 2010, 109:194-197.

13. Brechot $C$, Thiers V, Kremsdorf D, Nalpas B, Pol S, Paterlini-Brechot $P$ : Persistent hepatitis $B$ virus infection in subjects without hepatitis $B$ surface antigen: clinically significant or purely "occult"? Hepatology 2001, 34:194-203.

14. Zervou EK, Dalekos GN, Boumba DS, Tsianos EV: Value of anti-HBC screening of blood donors for prevention of $\mathrm{HBV}$ infection: results of a 3-year prospective study in Northwestern Greece. Transfusion 2001, 41:652-658.

15. Shang $G$, Seed $C R$, Wang $F$, Nie D, Farrugia A: Residual risk of transfusiontransmitted viral infections in Shenzhen, China, 2001 through 2004. Transfusion 2007, 47:529-539.

16. Fang Y, Shang QL, Liu JY, Li D, Xu WZ, Teng X, Zhao HW, Fu LJ, Zhang FM, Gu HX: Prevalence of occult hepatitis B virus infection among hepatopathy patients and healthy people in China. J Infect 2009, 58:383-388.

17. Shang G, Yan Y, Yang B, Shao C, Wang F, Li Q, Seed CR: Two HBV DNA +/HBsAg-blood donors identified by HBV NAT in Shenzhen, China. Transfus Apher Sci 2009, 41:3-7.

18. Bamaga MS, Azahar El, Al-Ghamdi AK, Al-Enzi FQ, Farahat FM: Nucleic acid amplification technology for hepatitis B virus, and its role in blood donation screening in blood banks. Saudi Med J 2009, 30:1416-1421.

19. Gonzalez R, Torres P, Castro E, Barbolla L, Candotti D, Koppelman M, Zaaijer HL, Lelie N, Allain JP, Echevarria JM: Efficacy of hepatitis B virus (HBV) DNA screening and characterization of acute and occult HBV infections among blood donors from Madrid, Spain. Transfusion 2009, 50:221-230.

20. Kwok S, Higuchi R: Avoiding false positives with PCR. Nature 1989, 339:237-238.

21. Raimondo G, Pollicino T, Cacciola I, Squadrito G: Occult hepatitis B virus infection. J Hepatol 2007, 46:160-170.

22. Lelie N, Heaton A: Hepatitis B - a review of the role of NAT in enhancing blood safety. J Clin Virol 2006, 36(Suppl 1):S1-2.

23. Offergeld R, Faensen D, Ritter S, Hamouda O: Human immunodeficiency virus, hepatitis $C$ and hepatitis $B$ infections among blood donors in Germany 2000-2002: risk of virus transmission and the impact of nucleic acid amplification testing. Euro Surveill 2005, 10:8-11.

24. Chevrier MC, St-Louis M, Perreault J, Caron B, Castilloux C, Laroche J, Delage $G$ : Detection and characterization of hepatitis $B$ virus of antihepatitis B core antigen-reactive blood donors in Quebec with an inhouse nucleic acid testing assay. Transfusion 2007, 47:1794-1802.

25. Owusu-Ofori S, Temple J, Sarkodie F, Anokwa M, Candotti D, Allain JP: Predonation screening of blood donors with rapid tests: implementation and efficacy of a novel approach to blood safety in resource-poor settings. Transfusion 2005, 45:133-140.

26. Wang DW, Wang TB, Liu FP, Shi LL: Study about seroconversion of HBV NAT screening-positive crowd from blood donors. Chinese Journal of Experimental and Clinical Virology 2008, 22:127-129.

27. Chen BY, Shen J: HBV-DNA detection in HBsAg negative blood donors and its clinical significance. Chinese Journal of Nosocomiology 2007 10:1240-1241.

28. Wang $D$, Tan $D$, Cao $X$ : A prospective study of posttransfusion hepatitis $B$ virus infection. Chinese Journal of Experimental and Clinical Virology 2000, 14:77-79.

29. Kreutz C: Molecular, immunological and clinical properties of mutated hepatitis B viruses. I Cell Mol Med 2002, 6:113-143.

30. Laulu SL, Roberts WL: The analytic sensitivity and mutant detection capability of six hepatitis B surface antigen assays. Am J Clin Pathol 2006, 125:748-751

31. Weber B: Diagnostic impact of the genetic variability of the hepatitis B virus surface antigen gene. J Med Virol 2006, 78(Suppl 1):S59-65.

32. Hollinger FB: Hepatitis B virus genetic diversity and its impact on diagnostic assays. J Viral Hepat 2007, 14(Suppl 1):S11-15.

33. Chemin I, Trepo C: Clinical impact of occult HBV infections. J Clin Virol 2005, 34(Suppl 1):S15-21

34. Gerlich WH, Glebe D, Schuttler CG: Deficiencies in the standardization and sensitivity of diagnostic tests for hepatitis B virus. J Viral Hepat 2007, 14(Suppl 1):16-21.
35. Hollinger FB, Sood G: Occult hepatitis B virus infection: a covert operation. J Viral Hepat 2010, 17:1-15.

36. Zerbini A, Pilli M, Boni C, Fisicaro P, Penna A, Di Vincenzo P, Giuberti T, Orlandini A, Raffa G, Pollicino T, Raimondo G, Ferrari C, Missale G: The characteristics of the cell-mediated immune response identify different profiles of occult hepatitis B virus infection. Gastroenterology 2008, 134:1470-1481.

37. Torbenson M, Thomas DL: Occult hepatitis B. Lancet Infect Dis 2002, 2:479-486

38. Komiya Y, Katayama K, Yugi H, Mizui M, Matsukura H, Tomoguri T, Miyakawa Y, Tabuchi A, Tanaka J, Yoshizawa H: Minimum infectious dose of hepatitis $B$ virus in chimpanzees and difference in the dynamics of viremia between genotype A and genotype C. Transfusion 2008, 48:286-294.

39. Candotti D, Allain JP: Transfusion-transmitted hepatitis B virus infection. J Hepatol 2009, 51:798-809.

40. Hoofnagle $\mathrm{JH}$, Waggoner JG: Hepatitis A and B virus markers in immune serum globulin. Gastroenterology 1980, 78:259-263.

41. Levicnik-Stezinar S, Rahne-Potokar U, Candotti D, Lelie N, Allain JP: Anti-HBs positive occult hepatitis $B$ virus carrier blood infectious in two transfusion recipients. J Hepatol 2008, 48:1022-1025.

42. Wendel S, Levi JE, Biagini S, Candotti D, Allain JP: A probable case of hepatitis B virus transfusion transmission revealed after a 13-month-long window period. Transfusion 2008, 48:1602-1608.

43. Jackson BR, Busch MP, Stramer SL, AuBuchon JP: The cost-effectiveness of NAT for HIV, HCV, and HBV in whole-blood donations. Transfusion 2003, 43:721-729.

44. Toyoda H, Hayashi K, Murakami Y, Honda T, Katano Y, Nakano I, Goto H, Kumada T, Takamatsu J: Prevalence and clinical implications of occult hepatitis B viral infection in hemophilia patients in Japan. J Med Virol 2004, 73:195-199.

45. Hui CK, Sun J, Au WY, Lie AK, Yueng YH, Zhang HY, Lee NP, Hou JL, Liang R, Lau GK: Occult hepatitis B virus infection in hematopoietic stem cell donors in a hepatitis B virus endemic area. J Hepatol 2005, 42:813-819.

46. Kim SM, Lee KS, Park CJ, Lee JY, Kim KH, Park JY, Lee JH, Kim HY, Yoo JY, Jang MK: Prevalence of occult HBV infection among subjects with normal serum ALT levels in Korea. J Infect 2007, 54:185-191.

47. Utama A, Octavia TI, Dhenni R, Miskad UA, Yusuf I, Tai S: Hepatitis B virus genotypes/subgenotypes in voluntary blood donors in Makassar, South Sulawesi, Indonesia. Virol J 2009, 6:128.

doi:10.1186/1743-422X-7-193

Cite this article as: Liu et al:: Detection of hepatitis B virus DNA among accepted blood donors in Nanjing, China. Virology Journal 2010 7:193.

\section{Submit your next manuscript to BioMed Central and take full advantage of:}

- Convenient online submission

- Thorough peer review

- No space constraints or color figure charges

- Immediate publication on acceptance

- Inclusion in PubMed, CAS, Scopus and Google Scholar

- Research which is freely available for redistribution 